\title{
HUBUNGAN KADAR KOLESTROL LOW DENSITY LIPOPROTEIN PLASMA DENGAN KADAR HIGH SENSITIVITY C-REACTIVE PROTEIN PADA REMAJA OBES
}

\author{
Daniel Budiono \\ Stefana H. M. Kaligis \\ Youla A. Assa
}

\begin{abstract}
Atherosclerosis is the leading cause of mortality in the developed countries and in the future, it is predicted to be the leading cause of mortality in the developing countries. Low density lipoprotein, high sensitivity C-reactive protein, and obesity have been identified as risk factors of atherosclerosis. Obesity during childhood and adolescents tends to occur during adults life. The aim of this study is to know the levels of low density lipoprotein and high sensitivity C-reactive protein and the correlation between those two levels in obese adolescents. This observational cross sectional study design involved 17 obese adolescents and analyzed using Spearman Correlation Test. The results showed the mean levels of LDL was 123,0 $\mathrm{mg} / \mathrm{dL}$, and hs-CRP was $1,618 \mathrm{mg} / \mathrm{L}$. Spearman correlation test showed significance value (p) was 0,024 and correlation significance value coefficient was 0,544. From the results can be concluded that the levels of low density lipoprotein levels in obese adolescents is in normal range, obese adolescents are associated with a moderate risk of cardiovascular disease at the future and there is a significant positive correlation between low density lipoprotein cholestrol levels and high sensitivity C-reactive protein levels in obese adolescents.
\end{abstract}

Keywords : low density lipoprotein, high sensitivity c-reactive protein, obese adolescents

\begin{abstract}
ABSTRAK
Aterosklerosis merupakan penyebab kematian utama di negara maju saat ini, dan diprediksi akan menjadi penyebab kematian utama di negara berkembang di masa mendatang. Peningkatan kadar low density lipoprotein dan kadar high sensitivity C-reactive protein (hsCRP) serta obesitas telah diidentifikasi sebagai faktor risiko aterosklerosis. Remaja yang mengalami obesitas cenderung tetap mengalami obesitas pada saat dewasa. Tujuan dari penelitian ini untuk mengetahui gambaran kadar kolestrol low density lipoprotein dan kadar high sensitivity C-reactive protein pada remaja obes, serta hubungan kadar low density lipoprotein dengan kadar high sensitivity C-reactive protein pada remaja obes. Penelitian ini menggunakan desain penelitian analitik observasional dengan pendekatan cross sectional terhadap 17 remaja obes. Nilai rerata kadar LDL pada remaja obes 123,00 mg/dL, dan nilai rerata kadar hs-CRP pada remaja obes $1,618 \mathrm{mg} / \mathrm{L}$. Berdasarkan hasil penelitian, dapat disimpulkan remaja obes memiliki kadar LDL dalam rentang normal, remaja obes memiliki risiko sedang terkena penyakit kardiovaskular di masa mendatang dan terdapat hubungan positif yang signifikan antara kadar low density lipoprotein dengan kadar high sensitivity creactive protein pada remaja obes.
\end{abstract}

Kata Kunci: low density lipoprotein, high sensitivity c-reactive protein, remaja obes 
Aterosklerosis merupakan penyebab kematian utama di negara maju saat ini. Aterosklerosis juga diprediksi akan menjadi penyebab kematian utama di negara berkembang pada masa mendatang. Prevalensi aterosklerosis sangat sulit diketahui secara pasti karena proses aterosklerosis bersifat asimtomatik, namun dampak dari proses aterosklerosis, yakni penyakit kardiovaskular merupakan penyebab kematian utama di seluruh dunia saat ini. ${ }^{1}$

Peningkatan kadar low density lipoprotein (LDL) dan kadar high sensitivity Creactive protein (hs-CRP) dalam darah telah diidentifikasi sebagai faktor risiko aterosklerosis. $^{2}$ Selain kadar LDL, ukuran partikel LDL juga menentukan aterogenitas LDL. Low density lipoprotein yang berukuran kecil padat (small dense LDL) merupakan subpopulasi LDL yang dikenal paling aterogenik. ${ }^{3}$ High sensitivity C-reactive protein merupakan protein yang disintetis di hati dibawah kontrol interleukin-6 sebagai respon terhadap berbagai rangsangan inflamasi baik inflamasi akut (infeksi) maupun inflamasi kronik (pembentukan plak ateroklerosis). High sensitivity C-reactive protein (hs-CRP) merupakan penanda inflamasi yang dianggap terbaik saat ini. ${ }^{4,5}$

Obesitas merupakan faktor risiko utama untuk terjadi aterosklerosis. ${ }^{6}$ Remaja yang mengalami obesitas berisiko tinggi untuk tetap menjadi obesitas pada masa dewasa. ${ }^{7}$

\section{METODE PENELITIAN}

Penelitian ini menggunakan desain penelitian analitik observasional dengan pendekatan cross sectional. Penelitian ini berlangsung dari bulan September 2013 sampai Januari 2014, dan dilaksanakan di Fakultas Kedokteran Universitas Sam Ratulangi Manado. Pengukuran kadar low density lipoprotein dan high sensitivity C-reactive protein dilakukan di Laboratorium Klinik.

Populasi dalam penelitian ini yaitu mahasiswa Fakultas Kedokteran Universitas Sam Ratulangi yang berusia di bawah 21 tahun yang memiliki indeks massa tubuh lebih dari persentil 95 menurut kurva CDC tahun 2000. Jumlah populasi tidak banyak, sehingga seluruh populasi yang bersedia menjadi responden, tidak sedang menderita penyakit infeksi dan penyakit kronik, tidak memiliki riwayat merokok atau mengonsumsi alkohol, tidak sedang meminum obat-obatan yang dapat mempengaruhi kadar lipid, dan tidak memiliki kelainan antropometri dipilih sebagai sampel penelitian.

\section{HASIL PENELITIAN}

Dari 24 orang yang menjadi populasi, hanya 17 orang dari populasi yang memenuhi kriteria inklusi dan kriteria eksklusi, yang menjadi sampel pada penelitian ini. Karakteristik responden berdasarkan jenis kelamin dapat dilihat pada tabel 1, sedangkan karakteristik responden berdasarkan usia dapat dilihat pada tabel 2 .

Tabel 1. Karakteristik Responden berdasarkan Jenis Kelamin

\begin{tabular}{lll}
\hline & Laki-laki & Perempuan \\
\hline Jumlah responden & 11 & 6 \\
\hline
\end{tabular}


Tabel 2. Karakteristik Responden berdasarkan Usia

\begin{tabular}{lll}
\hline Usia (tahun) & Jumlah Responden & $\%$ \\
\hline 17 & 8 & 47,1 \\
18 & 7 & 41,2 \\
18 & 1 & 5,9 \\
20 & 1 & 5,9 \\
\hline
\end{tabular}

\section{Kadar low density lipoprotein}

Kadar LDL responden yang berusia 17-18 tahun dikategorikan dengn menggunakan klasifikifasi yang dibuat oleh American Associaton for Clinical Chemistry. Empat belas responden memiliki kadar LDL dalam rentang kadar LDL yang normal (52-164 mg/dL). Hanya satu responden yang memiliki kadar LDL sedikit di atas rentang kadar LDL yang normal, yakni $166 \mathrm{mg} / \mathrm{dL}$.

Responden yang berusia 19 tahun dan 20 tahun masing-masing berjumlah satu orang. Kadar LDL responden yang berusia 19 tahun dan 20 tahun dikategorikan dengan menggunakan klasifikasi yang dibuat oleh National Cholestrol Education Program Adult Panel III (NCEP-ATP III). Responden yang berusia 19 tahun memiliki kadar LDL 127 mg/dL, sedangkan responden yang berusia 20 tahun memiliki kadar LDL 122 mg/dL. Kadar LDL kedua responden tersebut termasuk kategori kadar LDL yang mendekati optimal. Hasil pengukuran kadar low density lipoprotein responden dapat dilihat pada tabel 3

Tabel 3. Pengukuran Kadar Low Density Lipoprotein Responden

\begin{tabular}{|l|l|l|l|lr|}
\hline $\begin{array}{l}\text { Rerata Kadar } \\
\text { LDL }(\mathrm{mg} / \mathrm{dL})\end{array}$ & $\begin{array}{l}\text { Minimum } \\
(\mathrm{mg} / \mathrm{dL})\end{array}$ & $\begin{array}{l}\text { Maksimum } \\
(\mathrm{mg} / \mathrm{dL})\end{array}$ & Median (mg/dL) & $\begin{array}{l}\text { Standar } \\
(\mathrm{mg} / \mathrm{dL})\end{array}$ & Deviasi \\
\hline 123 & 63 & 122 & 122 & 28,460 & \\
\hline
\end{tabular}

\section{Kadar high sensitivity C-reactive Protein}

Nilai rata-rata kadar hs-CRP responden 1,618 mg/L dengan nilai minimum sebesar 0,2 mg/L, dan nilai maksimum sebesar 5,0 mg/L. Nilai median kadar hs-CRP responden 1,30 mg/L dengan standar deviasi 1,4613. Merujuk pada klasifikasi risiko penyakit kardiovaskular yang dibuat oleh American Heart Asociation, tujuh orang memiliki risiko rendah (kadar hsCRP $<1 \mathrm{mg} / \mathrm{L}$ ), delapan orang memiliki risiko moderat (kadar hs-CRP 1-3 mg/L), dan dua orang termasuk dalam kategori berisiko tinggi (kadar hs-CRP $>3 \mathrm{mg} / \mathrm{L}$ ) terkena penyakit kardiovaskular. Hasil pengukuran kadar high sensitivity $C$-reactive protein responden dapat dilihat pada tabel 4 .

Tabel 4. Pengukuran High Sensitivity C-Reactive Responden

\begin{tabular}{|l|l|l|l|lr|}
\hline $\begin{array}{l}\text { Rerata Kadar } \\
\text { hs-CRP }(\mathrm{mg} / \mathrm{L})\end{array}$ & $\begin{array}{l}\text { Minimum } \\
(\mathrm{mg} / \mathrm{L})\end{array}$ & $\begin{array}{l}\text { Maksimum } \\
(\mathrm{mg} / \mathrm{L})\end{array}$ & Median (mg/L) & $\begin{array}{l}\text { Standar } \\
(\mathrm{mg} / \mathrm{L})\end{array}$ & Deviasi \\
\hline 1,618 & 0,2 & 5,0 & 1,30 & 1,4613 & \\
\hline
\end{tabular}




\section{Hubungan kadar low density lipoprotein dan high sensitivity C-reactive protein}

Langkah pertama yang dilakukan untuk melakukan analisa bivariat, yaitu melakukan uji normalitas data dengan menggunakan uji Shapiro-Wilk. Uji normalitas Shapiro-Wilk dipilih karena jumlah sampel penelitian hanya 17 orang ( $<50$ sampel). Uji normalitas SahpiroWilk pada kadar LDL menunjukkan kadar LDL terdistribusi secara normal, namun data kadar hs-CRP tidak terdistribusi normal. Adanya data yang memiliki distribusi tidak normal merupakan dasar untuk melakukan pengujian hubungan kadar LDL dengan kadar hs-CRP dengan menggunakan uji nonparametrik Spearman.

Dari hasil uji nonparametrik Spearman didapatkan nilai signifikansi $(\rho)=0,024$ dan nilai koefisien korelasi $(r)=0,544$. Hasil uji nonparametrik Spearman dapat dilihat pada Tabel 5. Nilai signifikansi penelitian ini lebih kecil dari $\alpha(0,05)$, yang berarti bahwa kadar LDL memiliki hubungan yang signifikan dengan kadar hs-CRP. Koefisien korelasi berada dalam rentang 0,5-0,75 yang berarti bahwa kadar LDL dan kadar hs-CRP memiliki korelasi positif yang kuat. Gambar 1 menggambarkan hubungan korelasi kadar LDL dengan kadar hsCRP melalui grafik simple scater plot.

Tabel 5. Hasil Uji nonparametrik Spearman Hubungan Kadar Low Density Lipoprotein dan Kadar High Sensitivity C-Reactive Protein

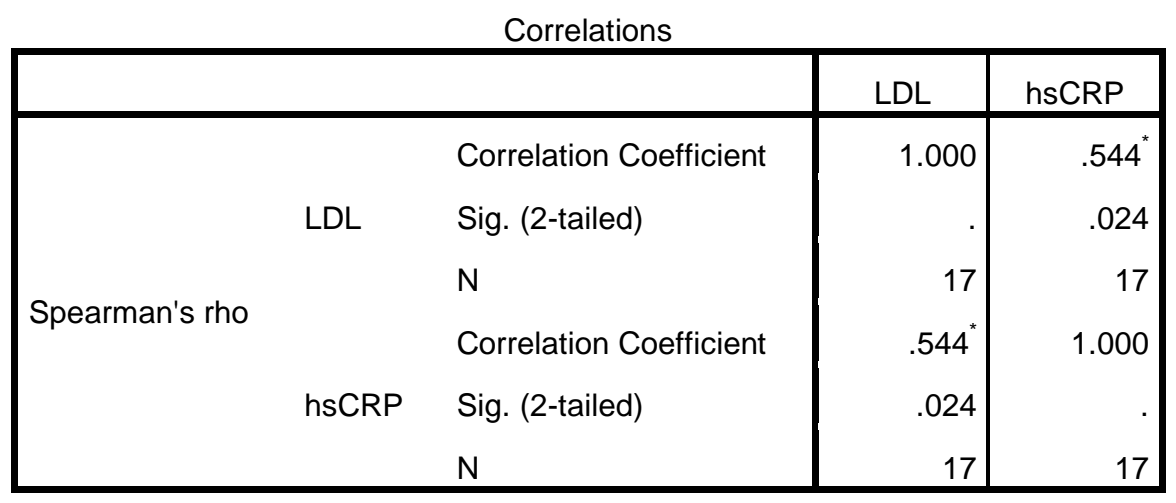

*. Correlation is significant at the 0.05 level (2-tailed).

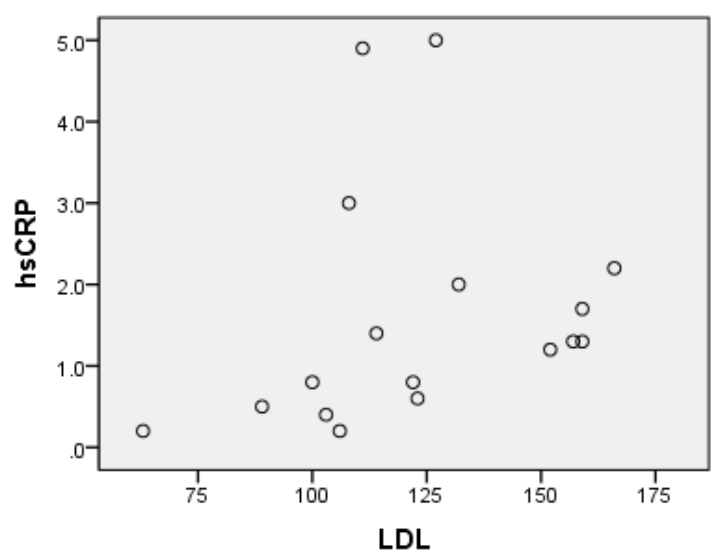

Gambar 1. Grafik simple scatter plot hubungan kadar low density lipoprotein dan kadar high sensitivity C-reactive protein 


\section{BAHASAN}

\section{Kadar low density lipoprotein pada remaja obes}

Nilai rerata (mean) kadar LDL pada responden 123,00 mg/dL. Berdasarkan klasifikasi kadar LDL untuk anak-anak dan remaja yang dikeluarkan oleh American Associaton for Clinical Chemistry, nilai rerata kadar LDL responden berada dalam rentang kadar LDL yang normal. Walaupun berada dalam rentang kadar LDL yang normal, kadar LDL yang dimiliki oleh responden lebih tinggi daripada kadar LDL yang dimiliki oleh remaja yang tidak obes. Penelitian yang dilakukan oleh Shirasawa dkk pada 2701 anak-anak di Jepang yang berusia 12-13 tahun dan tidak obes, ditemukan nilai rerata kadar LDL 86,0 mg/dL pada anak laki-laki dan 93,0 mg/dL pada anak perempuan. ${ }^{8}$ Penelitian yang dilakukan oleh Ford dkk menunjukkan nilai rerata kadar LDL dari 2724 remaja di Amerika Serikat yang berusia 12-17 tahun dan tidak obes, yaitu 90,2 mg/dL. ${ }^{9}$ Kadar LDL yang lebih tinggi pada remaja obes daripada remaja yang tidak obes juga ditemukan pada penelitian yang dilakukan oleh Mexitalia dkk dengan subjek penelitian pelajar SMP di Semarang. ${ }^{10}$

Remaja obes cenderung memiliki kadar LDL yang lebih tinggi dibandingkan dengan orang yang memiliki IMT normal. Obesitas merupakan keadaan akibat dari jumlah asupan energi yang lebih besar daripada jumlah penggunaan energi oleh tubuh. Kelebihan energi membuat zat-zat nutrisi dari makanan, seperti lemak, karbonhidrat, dan protein disimpan sebagai lemak di jaringan adiposa. Pada hati dan jaringan adiposa, terdapat banyak enzim lipoprotein lipase. Enzim lipoprotein lipase yang terdapat pada endotel kapiler akan menghidrolisis triasilgliserol pada VLDL, sehingga terbentuk IDL yang juga akan di hidrolisis oleh enzim lipoprotein lipase menjadi LDL.

\section{Kadar high sensitivity $C$-reactive protein pada remaja obes}

Nilai rerata kadar hs-CRP pada responden penelitian 1,618 mg/L. Nilai rerata kadar hs-CRP responden lebih tinggi daripada nilai rerata kadar hs-CRP anak-anak atau remaja yang tidak obes. Pada penelitian yang dilakukan oleh El Shorbagy dkk pada 100 anak obesitas yang berusia 6-16 tahun, ditemukan bahwa nilai rerata kadar hs-CRPnya 1,04 mg/L, sedangkan pada 50 anak yang memiliki indeks massa tubuh yang ideal memiliki, nilai rerata kadar hs-CRPnya 0,56 mg/L (48). Kadar high sensitivity C-reactive protein yang lebih tinggi pada remaja obes dari remaja yang tidak obes juga ditemukan oleh Harun dkk pada penelitian dengan subjek penelitian mahasiswa Universitas Hasanudin. ${ }^{11}$

Remaja obes memiliki kadar hs-CRP yang lebih tinggi daripada remaja yang memiliki IMT yang ideal. Pada obesitas, terjadi kondisi inflamasi kronik tingkat rendah terutama pada jaringan adiposa putih. Akumulasi makrofag sering ditemukan pada jaringan adiposa putih. Makrofag jaringan adiposa akan memproduksi beberapa sitokin proinflamasi, seperti TNF- $\alpha$, interleukin-6, monocyte chemotactic protein 1 , transforming growth factor $\beta 1$, dan faktor-faktor prokoagulan. Interleukin-6 akan menginduksi hati untuk memproduksi $C$ reactive protein. Pada orang yang mengalami obesitas, kadar adiponektinnya menurun. Adiponektin merupakan adipositokin yang diproduksi oleh jaringan adiposit, dan merupakan faktor yang menghambat ekspresi sitokin proinflamasi. ${ }^{12,13}$

\section{Hubungan kadar low density lipoprotein dan kadar high sensitivity C-reactive protein pada remaja obes}

Berdasarkan hasil uji statistik dengan menggunakan uji nonparametrik Spearman, kadar low density lipoprotein memiliki hubungan yang signifikan dan korelasi positif yang kuat dengan kadar hs-CRP pada remaja obes. Hasil penelitian ini konsisten dengan penelitian yang dilakukan oleh Kumar dkk. Penelitian yang dilakukan oleh Kumar dkk menemukan adanya korelasi positif antara kadar hs-CRP dengan konsentrasi LDL. ${ }^{14}$ Penelitian yang 
dilakukan oleh Lefrandt pada 41 pasien penyakit jantung koroner yang dirawat di Rumah Sakit Umum Manado juga menemukan bahwa kelompok kasus (pasien PJK) memiliki kadar LDL dan kadar hs-CRP yang lebih tinggi daripada kelompok kontrol (orang yang tidak menderita penyakit jantung koroner). ${ }^{15}$

Disfungsi endotel akan meningkatkan permeabilitas endotel sehingga LDL dapat masuk ke tunika intima arteri. Selanjutnya LDL akan mengalami oksidasi. Oksidasi ini dipicu oleh aktivitas radikal bebas yang dihasilkan dalam makrofag atau sel endotel di dinding arteri. Low density lipoprotein yang teroksidasi akan menghasilkan sitokin-sitokin inflamasi (IL-1, TNF- $\alpha$ ). Peningkatan sitokin-sitokin pro inflamasi (misalnya interleukin-6) menginduksi produksi reaktan fase akut dari hati seperti $C$-reactive protein (CRP), fibrinogen, dan serum amyloid A. ${ }^{3}$ Inilah sebabnya pada orang yang memiliki kadar LDL yang tinggi, seringkali juga memiliki kadar hs-CRP yang tinggi. ${ }^{16}$

\section{SIMPULAN}

Berdasarkan pengolahan data hasil penelitian yang telah dilakukan, dapat disimpulkan tiga hal. Pertama, remaja Obes memiliki kadar low density lipoprotein dalam rentang normal. Kedua, remaja Obes memiliki kadar high sensitivity c-reactive protein yang dalam kategori memiliki risiko sedang untuk terkena penyakit kardiovaskular di masa mendatang. Ketiga, yaitu kadar low density lipoprotein memiliki hubungan yang signifikan dan berkorelasi positif kuat dengan kadar high sensitivity C-reactive protein.

\section{SARAN}

Berdarkan hasil penelitian dapat disarankan untuk dilakukan penelitian yang mencari hubungan kadar low density lipoprotein dengan kadar high sensitivity C-reactive protein dengan skala populasi yang lebih besar atau subjek lebih banyak. Dapat juga dilakukan penambahan variabel jenis kelamin pada penelitian yang mencari hubungan kadar low density lipoprotein dengan kadar high sensitivity C-reactive protein. Kepada remaja obes, disarankan untuk dilakukan penyuluhan mengenai pola hidup sehat, yaitu berolahraga secara teratur dan makan makanan yang mengandung gizi seimbang,

\section{DAFTAR PUSTAKA}

1. Muis M, Murtala B. Peranan Ultrasonografi dalam Menilai Kompleks Intima-media Arteri Karotis untuk Diagnosis Dini Aterosklerosis. Cermin Dunia Kedokteran. 2011 April ;38(3):231-3.

2. International Atherosclerosis Society. Expert Dyslipidemia Panel. An International Atherosclerosis Society Position Paper : Global Recommendations for the Management of Dyslipidemia;2013.

3. Pusparini. Low density lipoprotein padat kecil sebagai faktor risiko aterosklerosis. Universa Medicina. 2006;25:22-32.

4. Arumalla VK, Kathyaini R. Serum high sensitivity c-reactive protein in different grades of obesity. Research Journal of Pharmaceutical, Biological and Chemical Sciences. 2011 Oct-Dec;2(4):1041-6.

5. Alwi I, Wijaya IK, Ranitya R, Muhadi, editors. Peran penanda biokimiawi jantung pada pasien dengan arteri koroner. Proceedings of the Simposium Pendekatan Holistik Kardiovaskular IX; 2010 July 02-04; Jakarta, Indonesia. Indonesia: Interna Publishing; 2010. 
6. Sugondo S. Obesitas. In : Sudoyo AW, Setiyohadi B, Alwi I, Simadibrata MK, Setiati S, editors. Buku ajar ilmu penyakit dalam. 5th ed. Jakarta: Interna Publishing, 2009; p.1975-80.

7. Hariyanto D, Madiyono B, Sjarif DR, Sastoasmoro S. Hubungan ketebalan tunika intima media arteri caroitis dengan obesitas pada remaja. Sari Pediatri. 2009; 11(3):159-66

8. Shirasawa T, Ochiai H, Ohtsu T, Nishimura R, Morimoto A, Hoshino H. LDLcholestrol and body mass index among Japanese school chlidren : a population-based cross-sectional study. Lipids in Health and Disease. 2013;12:1-6s.

9. Ford ES, Li C, Zhao G, Mokdad AH. Concentrations of low density lipoprotein cholestrol and total cholestroll among children and adolescents in the United States. Circulation. 2009;12:1108-15.

10. Mexitalia M, Utari A, Sakundarno M, Yamauchi T, Subagio HW, Soemantri A. Sindroma metabolik pada remaja obesitas. Media Medika Indonesiana. 2009;43(6):300-6.

11. Harun I, Hadju V, Taslim NA. Obesitas dan hsCRP pada remaja mahasiswa baru di Universitas Hasannudin. [cited 16 oktober 2013] Available from : pasca.unhas.ac.id

12. Sanchez AF, Santillan EM, Bautista M, Soto JE, Gonzales AM, Chirino CE et al. Inflammation, oxidative stress, and obesity. Int J Mol Sci. 2011; 12:3117-32.

13. Hummasti S, Hotaisligil GS. Endoplasmic reticulum stress and inflammation in obesity and diabetes. Circ Res. 2010; 107:579-91.

14. Kumar MD, Devi MRR, Kumar PS. High sensitive c-reactive protein - a risk marker for coronary artery disease. Journal of Dental and Medical Sciences (JDMS). 2012 Nov-Dec;2(3):28-32.

15. Lefrandt RL. The levels of hs-CRP in patients with coronary heart disease. Med $\mathrm{J}$ Indones. 204;13:102-6.

16. Strom JB, Libby P. Atheroschlerosis. In: Lilly LS, editors. Pathophysiology of heart disease. 5th ed. Philadelphia: Lippincott Williams \& Wilkins; 2011.p.113-33. 